\title{
SIGNIFICANCE OF LEUCOGRANITIC GNEISS IN THE ARCHEAN TETON RANGE
}

\author{
B. R. Frost, C. D. Frost, S. M. Swapp, L. Finley-Blasi, S. Stacey \\ DEPARTMENT OF GEOLOGY AND GEOPHYSICS \ UNIVERSITY OF WYOMING \ LARAMIE
}

\section{$\uparrow \quad$ INTRODUCTION}

In previous years of this project, we have developed the hypothesis that the high-pressure granulites exposed in the Moose Basin area of the Teton Range represent evidence of a 2.7 billion yearold continent-continent collision. We have described gneisses in the Teton Range that show two distinct metamorphic histories. In the northwest there are highpressure granulites suggesting metamorphism and deformation resulted from a 2685 to $2671 \mathrm{Ma}$ Himalayan type orogeny (Frost et al., 2006). Gneiss exposed in the northwest is dominated by migmatites, with lesser kyanite bearing pelite, and some garnet amphibolite. Their $\varepsilon_{\mathrm{Nd}}$ values at $2685 \mathrm{Ma}$ are negative. Thermobarometric studies in the northwestern gneiss suggest burial of pelitic rocks to the base of continental crust, with pressures reaching 12 kilobars and temperatures of $\sim 950^{\circ} \mathrm{C}$ during peak metamorphism (Fitz-Gerald, 2008). In modern plate tectonic environments these high pressures are associated with continent-continent collision. If the collisional hypothesis is correct, then this is the oldest documented example in the world.

The eastern and southern Teton Range gneisses record peak metamorphic pressures and temperatures of amphibolite grade (Fitz-Gerald, 2008), and migmatites are rare or absent. In the east, pelites are scarce and the only aluminosilicate present is sillimanite. Amphibolite rocks in the eastern Teton Range lack garnet unless they are iron-rich. Whereas the northwest rocks are negative, the southern and eastern $\varepsilon_{\mathrm{Nd}}$ values are positive, indicating that they formed from a different protolith. The contrast in features between rocks in the eastern and southern portion of the Teton Range to those in the northwest suggests the southern rocks were accreted after the 2707-2685 Ma high-pressure event.

In modern continental collision zones, such as the Himalayas, leucogranites intrude some millions of years after peak metamorphism. Leucogranitic gneiss is present in the Teton Range. The focus of this year's research was on these gneisses, which are mapped as Webb Canyon Gneiss. We studied the petrography and geochemistry of the Webb Canyon Gneiss to determine if there were one or more groups of gneisses included in this map unit. We undertook U-Pb zircon dating of Webb Canyon gneiss to determine its age with respect to peak metamorphism, which we previously established at $2707 \mathrm{Ma}$. We used chemical and isotopic data to interpret the source of the Webb Canyon gneiss. Finally, we compared the characteristics of the Webb Canyon gneiss to those of Himalayan leucogranites and determined the similarities and differences between the Archean and younger leucogranites.

Although we did not receive a research grant from the UW/NPS Research Station for our work in 2008-2009 we gratefully acknowledge housing and support at the AMK Ranch and our NSF grant EAR 0537670 that covered the costs.

\section{$\uparrow \quad$ METHODS AND MATERIALS}

In the summer of 2008 faculty and students from the University of Wyoming continued our studies of the geologic history recorded in the basement gneisses of the Teton Range. In 2008 we concentrated on the Webb Canyon gneiss, a silica-rich granitic gneiss that 
was emplaced late in the high-pressure metamorphism that affected the range. We conducted sampling traverses up Badger Creek, the Green Lakes region, and Camp Lake area on the western side of the range. We used AMK ranch as a base camp for traverses up Paintbrush Canyon, Ranger Peak, Coulter Canyon and Moran Canyon on the eastern side of the range.

We prepared thin sections to determine mineralogy and texture, used XRF and ICP-MS analysis of bulk rock powders to establish geochemical composition, and separated $\mathrm{Rb}, \mathrm{Sr}, \mathrm{Sm}$ and $\mathrm{Nd}$ from the same powders to obtain initial $\mathrm{Nd}$ and $\mathrm{Sr}$ isotopic compositions. U-Pb geochronology on zircon separates was done at Stanford's SHRIMP lab and Australian National University's LA-ICP-MS lab. Further analytical details are available in Finley-Blasi (2009).

\section{$\uparrow \quad$ RESULTS}

Preliminary results from this fieldwork show that the Webb Canyon gneiss is a leucogranite (i.e. granite with more than $70 \mathrm{SiO}_{2}$ ) and that it likely formed by melting of a rock like the layered gneiss. Most Webb Canyon gneiss is strongly foliated (Fig. 1), although some samples are coarser-grained and essentially undeformed.

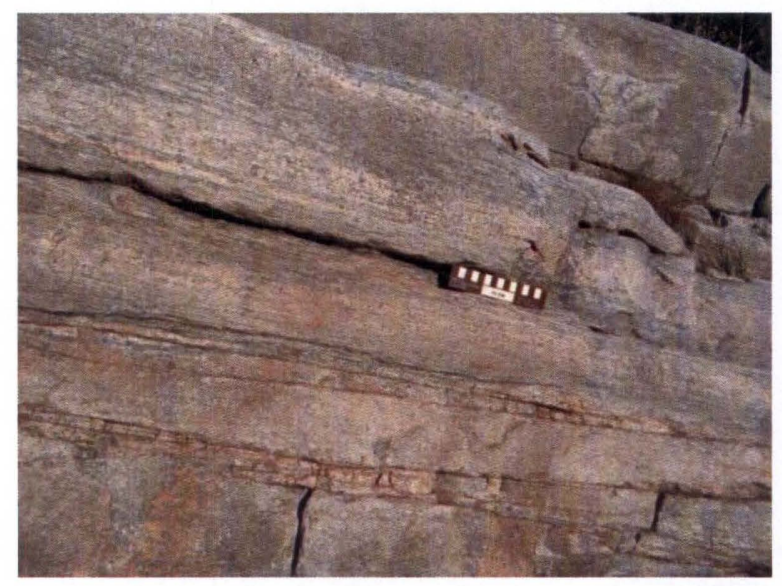

Figure 1. Typical field appearance of Webb Canyon gneiss, Waterfall Canyon area. Note strong foliation. Scale is marked in centimeters.

Most samples belong to what we describe as the "type" Webb Canyon gneiss, with distinctly high $\mathrm{SiO}_{2}$, calcic to calc-alkalic composition (Fig. 2) and "gullwing" shape REE patterns (Fig. 3). The coarsergrained, undeformed samples are more mafic and could be considerably younger. Both types may have garnet in some samples.
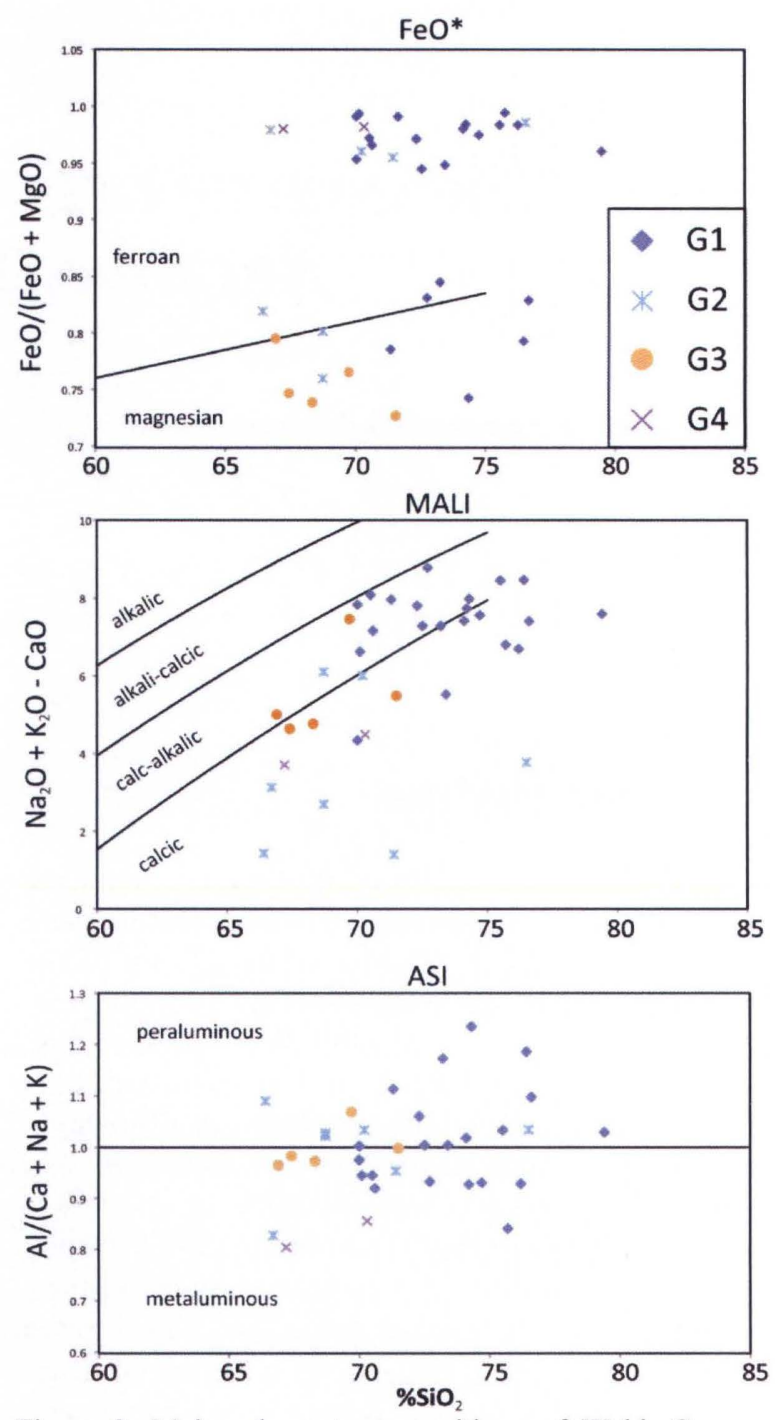

Figure 2. Major element compositions of Webb Canyon gneiss. The main "type" Webb Canyon gneiss is shown in blue diamonds; the undeformed variant is in orange circles.

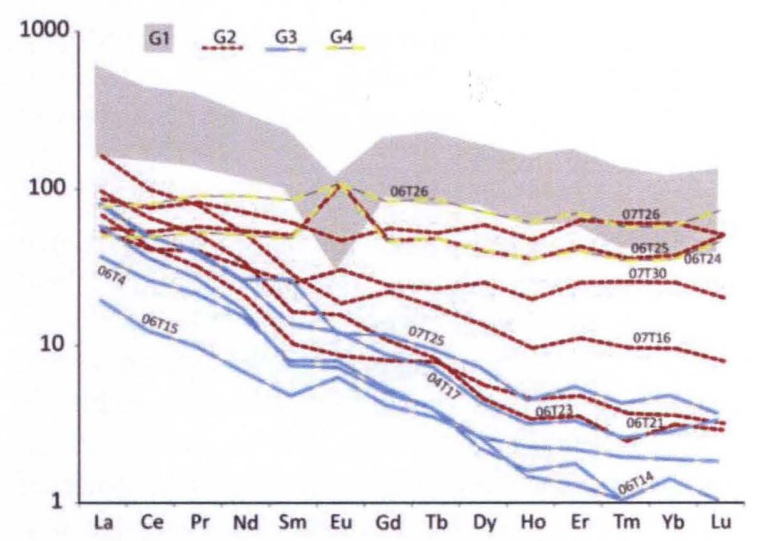

Figure 3. REE patterns of the type Webb Canyon gneiss exhibit little HREE depletion and have deep negative Eu anomalies. 
Zircon saturation temperatures for the type Webb Canyon gneiss are $>750^{\circ} \mathrm{C}$ (Fig. 4). If these temperatures approximate crystallization temperatures, then the Webb Canyon gneiss crystallized at a high temperature than many granites.

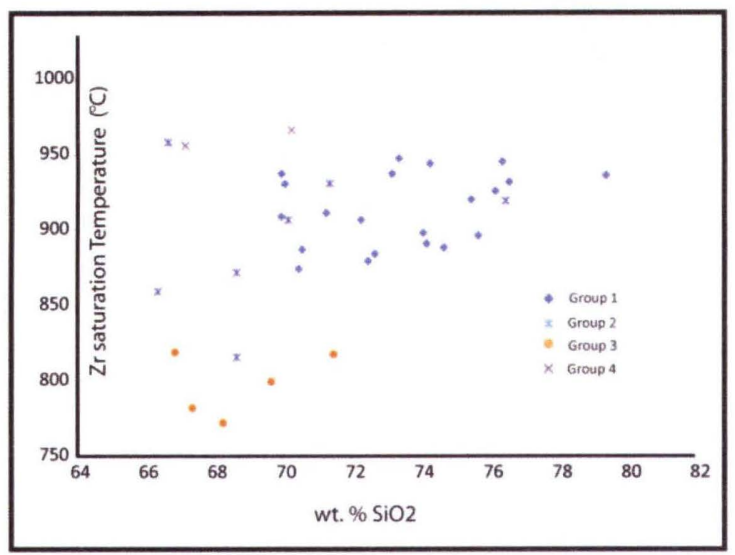

Figure 4. Zircon saturation temperatures for Webb Canyon gneiss, showing that the type Webb Canyon (blue diamonds) are uniformly high.

Our five high-precision dates, summarized below, suggest that the Webb Canyon Gneiss crystallized over a period of between 3 and 22 million years based upon the uncertainties associated with each $\mathrm{U}-\mathrm{Pb}$ zircon age determination.

\begin{tabular}{|l|l|l|}
\hline Sample & Location & Age \\
\hline $03 \mathrm{~T} 8$ & Northeast & $2683 \pm 3 \mathrm{Ma}$ \\
\hline $06 \mathrm{~T} 12$ & Central & $2675 \pm 3 \mathrm{Ma}$ \\
\hline $06 \mathrm{~T} 39$ & Northwest & $2677 \pm 3 \mathrm{Ma}$ \\
\hline $07 \mathrm{~T} 4$ & $\begin{array}{l}\text { East (garnet- } \\
\text { bearing) }\end{array}$ & $2685 \pm 5 \mathrm{Ma}$ \\
\hline $07 \mathrm{~T} 16$ & East (undeformed) & $2675 \pm 7 \mathrm{Ma}$ \\
\hline
\end{tabular}

Initial $\varepsilon_{\mathrm{Nd}}$ values for Webb Canyon Gneiss are mostly positive and overlap with values for the Layered gneiss (Fig. 5). This suggests that a young crustal source like the Layered Gneiss may have melted to produce Webb Canyon magmas.

\section{DISCUSSION}

The Webb Canyon gneiss exhibits many similarities with the leucogranites in the Himalaya, which formed by melting of pelitic gneisses during gravitational extension associated with over-thickened crust formed in the Himalaya during continent-continent collision of India with Asia (Fig 6a). The Webb Canyon gneiss, like Himalayan leucogranites, appears to be produced by crustal melting. Their age similarly post- dates peak metamorphism by around 20 million years, and leucogranites were emplaced over a period of time rather than being intrude in a single pulse. In both Tetons and Himalayas the leucogranites exhibit a sheetlike form (compare Fig. 6a and 6b).

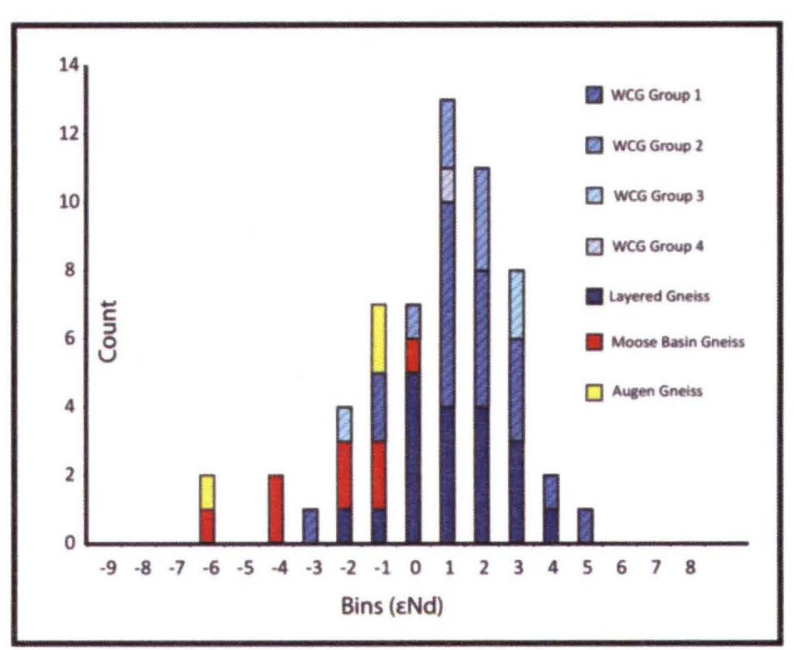

Figure 5. Initial epsilon Nd values at 2685 Ma for Archean rocks of the Teton Range. The western gneisses, including Moose Basin gneiss (red) are mainly negative, whereas the eastern Layered Gneiss and the Webb Canyon gneiss are mainly positive (blues). This suggests that the rocks that partially melted to make Webb Canyon granitic magmas had isotope characteristics like the eastern Layered Gneiss.
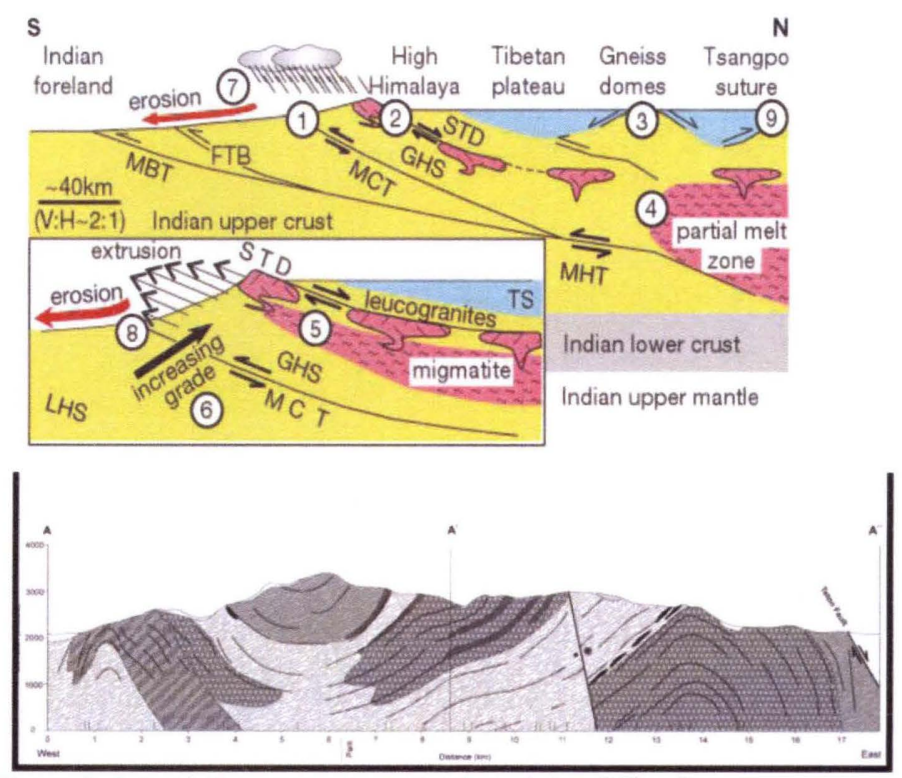

Figure 6. A (top) shows a cartoon for the origin of Himalayan leucogranites from Beaumont et al. (2001). Leucogranites are shown as pink plutons originated from partially melted, migmatitic rocks. B (bottom) shows a cross section through the northern Teton Range. The cross section is $18 \mathrm{~km}$ across. Webb Canyon gneiss is shown in the medium gray diamond pattern, and appears to be sheet-like. From Swapp et al. (in 
prep).

Unlike the Himalayan leucogranites, the Webb Canyon gneiss is more calcic, poorer in $\mathrm{Al}_{2} \mathrm{O}_{3}$, and mainly metaluminous instead of peraluminous. We interpret these differences to reflect the fact that the host material for the Webb Canyon gneiss was an Alpoor greywacke rather than an aluminous pelite, which melted to form the Himalayan leucogranites. The Webb Canyon gneiss also formed at much higher temperatures than the Himalayan leucogranites $\left(>750^{\circ} \mathrm{C}\right.$ as opposed to $<750^{\circ} \mathrm{C}$ ), which probably reflects differences in the tectonic environment between the two. Other differences include the dimensions of the leucogranite sheets, which appear to be smaller in the Tetons than in the Himalaya. However, this could be an artifact of the small area of exposed Archean crust that we have available to study in the Teton Range.

\section{$\downarrow$ Literature Cited}

Beaumont, C., R.A. Jamieson, M.H. Nguyen and B. Lee. 2001. Himalayan tectonics explained by extrusion of a low-viscosity crustal channel coupled to focused surface denudation. Nature.414:738-742.

Finley-Blasi, L. 2009. Origin and significance of the Webb Canyon gneiss, Teton Range, Wyoming. M.S. thesis, University of Wyoming, in preparation.

Fitz-Gerald, D.B. 2008. High-pressure granulites of the Teton Range. M.S. thesis, University of Wyoming.

Frost, B.R., C.D. Frost, M. Cornia, K.R. Chamberlain and R. Kirkwood. 2006. The Teton-Wind River domain: a 2.68-2.67 $\mathrm{Ga}$ active margin in the western Wyoming province. Canadian Journal of Earth Sciences. 43:1489-1510.

Swapp, S.M., B.R. Frost, C.D. Frost and'B. FitzGerald. in prep, $2.7 \mathrm{Ga}$ gneisses from the Teton Range, Wyoming: the oldest Himalayan-style orogeny on Earth.

For submission to Nature. 